Ольга Бадма-Халгаева

ORCID: 0000-0002-2621-5865

Академия будущего «Профессориум» Элиста, Россия

Виктория Пичугина

ORCID: 0000-0002-1195-725X

Лаборатория управления инновационными проектами и интеллектуальной собственностью ФГБНУ

«Институт стратегии развития образования РАО»

Национальный исследовательский университет «Высшая школа экономики»

Москва, Россия

\title{
Воинская добродетель богатырей в Калмыцких версиях героического эпоса Джангар
}

https://doi.org/10.34739/clit.2021.15.05

\section{Military Virtue of the Jangar's Warriors in the Kalmyk Versions}

The article defines the features of military virtue, which is given to the heroes from the Kalmyk version of the heroic Epic of Jangar. The main hero of the Epic is the hero Jangar, who rallied the heroes around himself and created the country of Bumba. All the songs of the Epic are associated with Jangar. The hero Jangar personifies a wise ruler and a brave warrior, who instructs his heroes and inspires them to exploits. Jangar and his heroes are not just brave warriors, but also bearers of unique characters and skills. Their individuality is emphasized in the descriptions of their actions, weapons and war horses. In the epic there are also young heroes, who following the example of the heroes, defend the country of Bumba from enemies. Since the Kalmyk "Jangar" is a composite work, the article compares songs belonging to the repertoires of different jangarchis: twelve songs translated by S. Lipkin (which includes ten songs from the repertoire of Eelyan Ovla), six songs from the repertoire of Mukeben Basangov translated by N. Bitkeev and three songs of the Maloderbetovsky version translated by A. Kichikov.

Keywords: the heroic epic of Jangar (Janggar), the oirat (oyrat) epic cycle, male characters in the epic Jangar (Janggar), didactic value of the epic of Jangar (Janggar), military virtue 
Джангар является эпическим циклом ойратов, который возник между XIV и XVIII вв. ${ }^{1}$ и состоит из нескольких десятков песен-поэм. Это составное произведение, где возраст самых древних частей может составлять около пятисот лет ${ }^{1}$. Джангар, рано как Илиада и Одиссея, является разновидностью героического эпоса, который сохранялся и передавался через поколения в устной форме. Этот эпос существует во множестве самостоятельных национальных версий.

Калмыцкая версия Джангара является значимой частью устной народной традиции ${ }^{2}$ и повествует о «золотом веке» ойратов - предков калмыков. В ней дается мифологическое описание событий условной эпохи, когда существовала страна Бумба и устанавливалась государственность кочевого народа: «Это было в начале времен, / В стародавний век золотой...»3. Каждая песня - это в некоторой степени независимая история об одном или нескольких приключениях героев, разделяющая общую структуру и основные элементы: вступительная часть, содержащая важную информацию о стране Бумба, власти Джангара и его славных делах, а также его смелых воинах, их добродетельных женах (невестах) или сыновьях. Песни Джангара, с одной стороны, сюжетно связаны и не противоречат друг другу, а с другой - самостоятельные по содержанию поэмы, каждая из которых «при самостоятельном исполнении произведет впечатление целого Джангара в миниатюре»4. В современном понимании калмыцкий Джангар - это совокупность репертуаров нескольких школ и версий, в основе которых десять песен из репертуара Ээляна Овла. Действие эпоса происходит в географических координатах, часть из которых являются вымышленными ${ }^{5}$, но ни одна из них не связана с географическими названиями в пределах Поволжья, что указывает на древнее происхождение соответствующих частей Джангариады. Сюжет каждой песни разворачивается как цепь богатырских подвигов, совершаемых во имя защиты своей страны и

\footnotetext{
1 Предположительно, верхняя граница связана со временем сложения ойратского каганата в конце XIV в., а нижняя - с бегством калмыков из России в 1771 г. или даже более поздними событиями.

${ }^{2}$ Literaturen der Völker der Sowjetunion, (ed.) H. Jünger, Leipzig 1967.

3 Джангар. Калмыцихй народный эпос, пер. С.И. Липкина, Элиста 1977, с. 17.

4 А.Ш. Кичиков, Герочческий эпос «Джангар»: сравнительно-типологическое исследование памятника, Москва 1994, с. 173.

5 С.М. Мургаев, «Джангар»: основы геополитических взглядов средневекового калмыцкого общества, [в:] "Джангар» в евразийском пространстве: к 20о-летию первой публикации калмыцкого герочческого эпоса «Джан-гар», Элиста 2004.
} 
родных кочевий: «...песни калмыцкого Джангара в болышинстве односюжетны (исключение составляют песни о поражении Хара Киняса и Шара Гюргю), то есть богатырь в течение всего эпического повествования ведет борьбу с одним основным врагом, в конечном счете, одерживает над ним победу» ${ }^{6}$.

Несмотря на то, что письменная ойратская литература и Джангар как ее основной памятник являются значимой для изучения областью, она привлекает не слишком много исследовательского внимания. Вероятно, из-за того, что эта литература охватывает ограниченный промежуток времени, не слишком велика по объему и мало доступна в текстах, представленных в библиотеках и переводах на другие языки (что особенно касается калмыцкой версии Джангара $)^{7}$. В рамках данной статьи мы будем опираться на ставший классическим перевод С.И. Липкина, содержащий двенадцать песен, и указывать в скобках номер песни, а также обращаться к шести песням из репертуара Мукебена Басангова (пер. Н.Ц. Биткеева) и трем песням Малодербетовской версии (пер. А.Ш. Кичикова), указывая в скобках соответственно РМБ или МВ.

\section{Воинская доблесть Джангара как богатыря-правителя}

Вопросы о том, что именно означало имя главного героя и название его страны, до сих пор являются дискуссионными. Имена собственные и географические наименования, хоть и вымышленные, всегда включаются в эпос с умыслом и отвечают задачам раскрыть особенности жизненного пути героя и основные линии повествования. В эпосе нет ни одного исторического имени, а имя главного героя представляет самую большую загадку ${ }^{8}$. Если согласиться с гипотезой о том, что имя Джангара связано с одиночеством, то «эта черта не играет роли в его истории» и речь идет лишь об архетипе героя-одиночки 9 . Джангар не является героем, который не знает своего родства и

\footnotetext{
6 Э.Б. Овалов, Типология мотивов и сюжетов в эпосе монгольских народов, Элиста 2004, c. 60.

7 J.R. Krueger, Written oirat and kalmyk studies, „Mongolian Studies” 1975, Vol. 2, p. 111.

8 По одной из версий имя Джангра идет от персидского «джихангир» через татарское или киргизское «джангир» и означает «покоритель мира», а по другой связано с казахским, якутским, шорским или тунгусо-монгольским именем, переводимым как «одинокий», «сирота».

9 E.M. Mélétinsky, La poétique historique du folklore narrative, „Ethnologie française, nouvelle serie" 1996, T. 26, No. 4, p. 616.
} 
происхождения, его происхождение лишь окутывается ореолом таинственности: «Круглым остался он сиротой. / Так о нем говорят: / Такй-Зулы-хана он семенем был, / Тангсык-Бумбы-хана внуком он был, / Узюнга великого сыном он был»10. Генеалогия Джангара отличается в разных калмыцких версиях, но она имеет особую значимость для эпоса. В значении имени главного героя, так или иначе, зафиксирована традиция изложения деяний героя как первопредка, первого и великого человека.

Джангар и его воины-богатыри подчеркивают знатность своего происхождения, постоянно указывая на то, что они являются ханскими сыновьями. Эти и другие мотивы указывают на то, что Бумба является союзным государством. Слово «бумба», имеющее в калмыцком языке несколько значений (купол, памятник, здания со святынями, священный сосуд для воды), и в эпосе является многозначным. Название страны можно предположительно трактовать как вершину человеческих желаний (по аналогии с вершиной купола) или как страну, характеризующуюся эпитетами «священная», «заветная», «непобедимая» с оттенком «запретная» ${ }^{11}$. Защита страны Бумба и поддержание ее благополучия - основная идея “Джангариады”: «Ужели сражений для славы нет? Сайгаков и тех для облавы нет? Ужели для боя державы нет? Ужели врага для расправы нет?»12.

Войны, связанные с активной территориальной экспансией Джангара, и оборонительные войны, где богатыри совершают множество подвигов, имели огромное значение для Джангара и его богатырей. Рано повзрослев и познав основы военного дела, Джангар одержал серию побед и покорил множество территорий, «властно расширив свои рубежи». И все это было предначертано ему по рождению: «Из людей он один рожден / Из начала мира сего / Стать владыкой мира всего, / И могучим и славным стать, / Ханом семидержавным стать...» ${ }^{13}$. Войны, в которых участвует Джангар и его богатыри, представлены как необходимые для отстаивания свободы страны и чести ее правителя, в чем ему помогают его богатыри. В одной из песен повествуется о поединке Джангара с провидцем

\footnotetext{
10 Джангар, op. cit., с. 17.

${ }^{11}$ С.А. Козин, Джангариада, Элиста 1998, с. 95.

12 Джангар, op. cit., c. 28.

13 Ibidem, c. 29.
} 
Алтаном Цеджи, где Джангару помогает Хонгор: «Увидал Алтан Цеджи:/ Мчатся могущественные друзья. / "Мне бороться с ними нельзя, / Буду сразу же побежден. / Если соединился нойон / С Хонгором, драться напрасно мне/ Надо сдаваться, ясно мне”» ${ }^{14}$. Цеджи предсказывает, что Джангар прославит свое имя, его враги будут повержены, а народ - счастлив. Победив Алтана Цеджи, Джангар делает его главой правого полукруга своих богатырей, а главой левого полукруга - Хонгора (или Гюмбе, потому что он «толкователь снов»; Пролог, МВ, пер. А.Ш. Кичикова).

С Джангаром так или иначе связаны все песни эпоса: даже в тех песнях, где он не играет значимую роль, Джангар координирует деятельность своих богатырей, наставляет их в правильных решениях и отводит от решений неправильных. Богатыря Мингйана отправил к хану Кюрмену, «утешив» его тем, что он сможет захватить хана или попадет в плен, но останется лучшим среди певцов. В убеждении богатырей выступить в бой против кого бы то ни было, Джангару не было равных: «Трусы, - пойдет о нас разговор. - Недруг у них угнал табуны, - Дома лежат и боятся войны!»15.

«Джангар воспитывал своих богатырей личным примером, находил нужные слова для тех из них, кого считал близкими друзьями, учил не боятся вступать в смертельный бой» ${ }^{16}$, хотя иногда посылал вместо себя своих богатырей (как это было например с Мингйаном, которого отправили к хану Кюрмену, бросившему вызов именно Джангару).

Несмотря на некоторое не совсем героическое поведение, Джангар олицетворял идеального правителя, который создал идеальное государство и постиг четыре истины, которыми, согласно буддизму, были мучение, умножение мучений, торжество над мучениями и знание, ведущее к победе над мучениями. Объединяющему народ правителю дана такая характеристика:

\footnotetext{
14 Ibidem, c. 36.

15 Ibidem.

${ }^{16}$ О.Ю. Бадма-Халгаева, Педагогические константы в героическом эпосе «Джангар», [в:] Проблемы и перспективы развития современного образования в контексте его историко-педагогической интерпретации, сб. науч. трудов Международной научнопрактической конференции - XXXIII сессии Научного совета по проблемам истории образования и педагогической науки при отделении философии образования и теоретической педагогики РАО, Санкт-Петербург 2020, с. 474.
} 
«Джангар, мудрый в совете, отважный в борьбе! / Светоч, народам указывающий путь!»17.

\section{Воинская доблесть богатырей Джангара}

Богатыри, поклявшиеся Джангару в верности подчиняются ему как нойоны-феодалы: «Клятву мы дали друг другу, мой хан: / Соединить свои жизни навек, / Жить на земле, как один человек...»18. Они являются не просто смелыми воинами, но и носителями уникальных характеров, воплощая девяносто девять ратных доблестей, в число которых входило соблюдение законов, обычаев и традиций, а также участие в обрядах, состязаниях и военных походах. Богатырей объединяет то, что «героические подвиги они совершают благодаря своей храбрости, огромной физической силе и нравственной потребности служить Джангару, умножая могущество Бумбы»19. Богатыри часто называются «Джангаровы львы» (пер. С.И. Липкина) или «львоподобные богатыри» (MB; пер. пер. А.Ш. Кичикова) и характеризуются, с одной стороны, как пребывающие в покое или, наоборот, в хмельном веселье воины, а с другой - как воины, всегда готовые выпить арзы и ринуться в бой. Каждый воин обладает своим видом оружия, которое наделено собственным именем, что указывает на него как атрибут конкретного героя. Помощниками героев являются их кони с уникальными характерами, которых ценят и уважают как друзей. Так, рыжего коня Джангара ведут к дверям дворца сорок четыре молодца; этот конь не просто красив и силен, он рассматривается как носитель мудрости: «Но, резвясь, не забывал / О переходе трудном он: / Не был конем безрассудным он!»²0.

Сопоставив разные версии, можно составить следующий обобщенный портрет некоторых из богатырей Джангара. Правой рукой Джангара является богатырь Хонгор, который превосходит Джангара в силе и успешен в состязаниях по борьбе (РМБ). Хонгор владеет мечом по имени Шаджин Шарбанг и плетью по имени Хашил Тарни, похожую на «чешуйчатую змею» (Пролог, МВ; пер.

\footnotetext{
17 Джангар, op. cit., с. 342.

${ }^{18}$ Ibidem, c. 142.

19 А.Ш. Кичиков, Герочческий..., оp. cit., с. 5 .

20 Джангар, op. cit., с. 42.
} 
А.Ш. Кичикова). Иногда Хонгов использует в битвах в качестве оружия огромное сандаловое дерево. Конь Хонгора - Кеке-Галзан - несколько медлительный, но сильный и смелый, как и его хозяин. Богатырь Санал, помимо традиционных богатырских качеств, является астрологом и способен узнать будущее по небесным светилам. Он мастерски владеет саблей, а его конь - Бурал Галзан - является самым старым из богатырских коней, потому что ему двадцать четыре года (РМБ). Богатырь Савар, которого назвают неистовым, владеет секирой по имени Шабар Шюгин и кобылицей Кюрюнг-Галзан, которая разговаривает с ним на равных и даже иногда угрожает богатырю (РМБ). Богатырь Мингйан известен своей красотой, певческими и музыкальными способностями. Это богатырь-оборотень, способный превращаться то в маленького мальчика, то в паука, то в змею. В одном из походов, чтобы не привлекать внимания, он превратил своего коня Алтана Шарга «в захудалого меринка»"21. Богатырь Алтан Чэджи является провидцем и может гадать во сне; он обладатель коня по имени Аксак-Улан. Гюзян-Гюмбе - богатырь-толстяк, которого можно увидеть за столом, а не на поле боя. Этот богатырь умеет гадать по бараньей лопатке (РМБ) и имеет соответствующего ему коня, несколько похожего на слона.

Оружие и доспехи являются неотъемлемым атрибутом воина, и в эпосе экипировка богатыря часто отражает особенности его характера и указывает на особые воинские умения. В песне о женитьбе Хонгора мы находим как он надевает боевые латы и пояс, берет «односаженный меч стальной в семьдесят меринов ценой» ${ }^{22}$. Хонгор владеет огромным луком, что является почти уникальным умением среди богатырей. Оружие богатырей Джангара часто определяется как волшебное, поражая не только своими размерами, но и характеристиками (прочностью, ударной силой, тонкостью исполнения и украшения и т.д.). Нагайка Джангара описана так: «Из шкуры трехлетнего быка / Сердцевина ее сплетена. / Снаружи покрыта шкурой она / Четырехлетнего быка. / Напоминают узоры ее / Узоры на спине змеи. / Варили ее в слюне змеи, / Опускали в отраву ее, / Укрепили на славу ее. / Взгляните на оправу ее: / Стальные пуговки на ней - / Сразу всех не сосчитать; / С красным шелковым ремешком /

${ }^{21}$ Ibidem, c. 71.

${ }^{22}$ Ibidem, c. 50. 
Сандаловая рукоять; / Стальная на самом конце ладонь: / Станешь бить - обожжет, как огонь!» ${ }^{23}$. Описания такого рода создают парадокс: портрет каждого героя достигается через детализацию его воинской атрибутики, а не через особое внимание к его внешности и одежде. Причина появления в Джангаре визуализации такого рода неясна 24.

Служение богатырей Джангару - это не только серия военных побед, но и череда проявлений смекалки, ловкости и хитрости. В Джангаре «при доминирующем типе сюжета о борьбе с внешними врагами одной из тематических особенностей является наличие повествований о поездках богатырей на поиски похищенного объекта и (или) к далекой невесте» 25 . Баланс физической силы и нравственной красоты представлен в Джангаре как достигающийся благодаря мудрости. Неслучайно Алтан Чэджи говорит о Санале: «С трудной задачей справится он, / В стане чужом прославится он, / Победителем явится он! / Мне, мудрому, равен умом» ${ }^{26}$.

\section{Воинская доблесть детей - богатырей Джангара}

Иерархическая структура бумбайского общества демонстрирует не только прочные межпоколенные связи, но и то, что воспитание новых поколений богатырей будет основано на традиции, которая знакома и привычна старшему поколению богатырей Джангара. Чтобы порядок и благоденствие страны были постоянными, нужно, чтобы подрастало новое поколение богатырей страны Бумба. Именно на это указывает Джангар, когда рассказывает желающим померяться силой юношам о своем детстве и поединке, в котором он проиграл, но который многому его научил ${ }^{27}$.

Мотив мальчика - помощника героя - в калмыцком Джангаре не получил развития ${ }^{28}$; в эпосе присутствуют и совершают подвиги малолетние герои, у которых перед глазами пример взрослых

\footnotetext{
23 Ibidem, c. 42.

24 А.А. Бурыкин, Индивидуализация образов персонажей как средство композиции и сюжетообразования в калмыцком герочческом эпосе “Джангар», „Studia Culturae” 2002, № 3, c. 81 .

${ }_{25}$ А.Ш. Кичиков, Герочческий..., ор.cit., с. 6.

${ }^{26}$ Джангар, op. cit., с. 101.

27 Ibidem.

28 Э.Б. Овалов, Типология..., op.cit., с. 46-47.
} 
богатырей. Сам Джангар и Хонгор с трех лет бьются с врагами, что потом повторяют их сыновья: трехлетний сын Джангара Шовшур возвращает из рабства народ Бумбы, а сын Хонгора Хошун-Улан ${ }^{29}$ сразу рождается с оружием в руках и также отличается героизмом. Шовшур не является сыном ханши Шавдал, законной жены Джангара. Ради обретения наследника Джангар покидает страну Бумба и внезапно отправляется на чужбину. Родившемуся Шовшур дана следующая характеристика: «Только блеснуло солнце третьего дня, / Новорожденный сел уже на коня / И поскакал на охоту, - пищи достать, / Чтоб накормить и отца и милую мать»30. Дети богатырей, как и все дети, иногда проявляют упрямство. В эпосе даже присутствует эпизод наказания сына Джангара за упрямство: «Вечером поздно вернулся Шовшур домой, / И на пороге отец встречает его / И говорит: "Поглядите, как сын дурной / Честное имя позорит отца своего! / Ты почему мне чужого двухлетку привел? / Разве тебе для того я жизнь даровал, / Чтобы в кочевьях ты жеребят воровал?” - / Джангар схватил малыша за стальной подол / И, в исполинской руке Шовшура вертя, / Тридцать раз оземь ударил свое дитя. / Слово не молвил нойону юный смельчак, / Только надел свалившийся медный шишак / И, напоив Аранзала, отправился спать» 31 .

В Джангаре «присутствуют описания инициальных испытаний, предшествующих посвящению юноши в воины, которые проходил и сам Джангар. За рождением богатыря в обязательном порядке следовало наречение именем, которое предрекало будущее» ${ }^{2}$.

\section{Воинская добродетель болыших и маленьких богатырей}

Джангар и его богатыри олицетворяли «норму поведения человека героического»33, которая сформировалась на основе

\footnotetext{
29 Сын Хонгора является главным героем в песне из репертуара М. Басангова $O$ том, как Хонгор доставил Джангару шлем, именуемый Дун, и меч, испускающий молнии при атаке, Хара Бирмис-хана. Героями песни О трех мальчуганах: о Хошун Улане, о Хара Джилгане, об Аля Шонхоре являются сын Хонгора, сын Джангара и сын Алтан Чэджи соответственно, то есть здесь речь идет о другом сыне Джангара.

30 Джангар, op. cit., с. 276.

${ }^{31}$ Ibidem, c. 278.

${ }^{32}$ О.Ю. Бадма-Халгаева, Педагогические..., ор. cit., с. 475.

33 Ц.Б. Селеева, Специфическое и универсальное в образе героя калмыцкой богатырской сказки и эпоса «Джангар», „Вестник Калмыцкого института гуманитарных исследований РАН” 2015, № 2, с. 152.
} 
обширного свода правил по добродетельному поведению правителя, воина и семьянина. Физическая сила героев сочеталась с умом, самоотверженностью, трудолюбием, талантом или даже даром. Благополучие страны Бумба полностью зависело от многовековых практик поведения, подобающих правителю и его воинам. В Джангаре жизненный цикл богатыря не завершается смертью: «Смерть выходит за рамки собственно биографических мотивов эпоса, она представляется финалом богатырского поединка, исходом которого является или позорное поражение, равное смерти, или подвиг, то есть бессмертие»34. Джангар можно рассматривать как эпос о бесстрашных воинах, рядом с которыми всегда были старшие (по возрасту или статусу) товарищи, поддерживающие и наставляющие младших, которым только предстояло стать бесстрашными богатырями страны Бумба.

\section{Литература}

Krueger J.R., Written oirat and kalmyk studies, „Mongolian Studies” 1975, Vol. 2, p. 93-113.

Literaturen der Völker der Sowjetunion, (ed.) H. Jünger, Leipzig 1967.

Mélétinsky E.M., La poétique historique du folklore narrative, „Ethnologie française, nouvelle serie" 1996, T. 26, No. 4, p. 611-618.

Бадма-Халгаева О.Ю., Педагогические константы в героическом эпосе «Джангар», [в:] Проблемы и перспективы развития современного образования в контексте его историко-педагогической интерпретации, сб. науч. трудов Международной научно-практической конференции - XXXIII сессии Научного совета по проблемам истории образования и педагогической науки при отделении философии образования и теоретической педагогики РАО, Санкт-Петербург 2020.

Бурыкин А.А., Индивидуализация образов персонажей как средство композиции и сюжетообразования в калмыцком героическом эпосе «Джангар», „Studia Culturae” 2002, № 3, c. 79-94.

Джангар. Калмыцкий народный эпос, пер. С.И. Липкина, Элиста 1977.

Джангар. Малодербетская версия, пер. А.Ш. Кичикова, Элиста 1999.

«Джангар». Эпический репертура Мукебюна Басангова, пер. Н.Ц. Биткеева, Элиста 1988.

Кичиков А.Ш., Героический эпос «Джангар»: сравнительно-типологическое исследование памятника, Москва 1994.

34 Е.Э. Хабунова, Герочческий эпос «Джангар»: поэтические константы богатырского жизненного цикла (сравнительное изучение национальных версий), Ростов-на-Дону 2006. 
Козин С.А., Джангариада, Элиста 1998.

Мургаев С.М., «Джангар»: основы геополитических взглядов средневекового калмыцкого общества, [в:] «Джангар» в евразийском пространстве: $\kappa$ 20о-летию первой публикации калмыцкого герочческого эпоса «Джан-гар», Элиста 2004.

Овалов Э.Б., Типология мотивов и сюжетов в эпосе монгольских народов, Элиста 2004.

Селеева Ц.Б., Специфическое и универсальное в образе героя калмыцкой богатырской сказки и эпоса «Джангар», „Вестник Калмыцкого института гуманитарных исследований РАН” 2015, № 2, с. 151-155.

Хабунова Е.Э., Героический эпос «Джангар»: поэтические константы богатырского жизненного циикла (сравнительное изучение национальных версий), Ростов-на-Дону 2006.

\section{References}

Badma-Halgaeva O.Û., Pedagogičeskie konstanty $v$ geroičeskom èpose «Ď̌angar», [v:] Problemy $i$ perspektivy razvitiâ souremennogo obrazovaniâv kontekste ego istoriko-pedagogičeskoj interpretacii, sb. nauč. trudov Meždunarodnoj naučno-praktičeskoj konferencii - XXHIII sessii Naučnogo soveta po problemam istorii obrazovaniâ i pedagogičeskoj nauki pri otdelenii filosofii obrazovaniâ i teoretičeskoj pedagogiki RAO, Sankt-Peterburg 2020.

Burykin A.A., Individualizaciâ obrazov personažej kak sredstvo kompozicii $i$ sûžetoobrazovaniâ v kalmyckom geroičeskom èpose «Džangar», „Studia Culturae" 2002, № 3, s. 79-94.

Džangar. Ėpičeskij repertura Mukebûna Basangova, per. N.C. Bitkeeva, Èlista 1988.

Džangar. Kalmyckij narodnyj èpos, per. S.I. Lipkina, Èlista 1977.

Džangar. Maloderbetskaâ versiâ per. A.Š. Kičikova, Èlista 1999.

Habunova E.È., Geroičeskij èpos «Džangar»: poètičeskie konstanty bogatyrskogo žiznennogo cikla (sravnitel'noe izučenie nacional'nyh versij), Rostov-naDonu 2006.

Kičikov A.Š., Geroičeskij èpos «Džangar»: sravnitel'no-tipologičeskoe issledovanie pamâtnika, Moskva 1994.

Kozin S.A., Džangariada, Èlista 1998.

Krueger J.R., Written oirat and kalmyk studies, „Mongolian Studies” 1975, Vol. 2, p. 93-113.

Literaturen der Völker der Sowjet Union, (ed.) H. Jünger, Leipzig 1967.

Mélétinsky E.M., La poétique historique du folklore narrative, „Ethnologie française, nouvelle serie" 1996, T. 26, No. 4, p. 611-618. 
Murgaev S.M., «Džangar»: osnovy geopolitičeskih vzglâdov srednevekovogo kalmyckogo obŝestva, [v:] «Džangar» $v$ evrazijskom prostranstve: $k$ 20oletiû pervoj publikacii kalmyckogo geroičeskogo èposa «Džan-gar», Èlista 2004.

Ovalov È.B., Tipologiâ motivov i sûžetov vèpose mongol'skih narodov, Èlista 2004.

Seleeva C.B., Specifičeskoe iuniversal'noe v obraze geroâ kalmyckoj bogatyrskoj skazki i èposa «Džangar», „Vestnik Kalmyckogo instituta gumanitarnyh issledovanij RAN” 2015, № 2, c. 151-155. 